\title{
Algae-based biofuel production as part of an industrial cluster
}

Viktor Andersson, Sarah Broberg, Roman Hackl, Magnus Karlsson and Thore Berntsson

\section{Linköping University Post Print}

\section{Tweet}

N.B.: When citing this work, cite the original article.

Original Publication:

Viktor Andersson, Sarah Broberg, Roman Hackl, Magnus Karlsson and Thore Berntsson, Algae-based biofuel production as part of an industrial cluster, 2014, Biomass and Bioenergy, (71), 113-124.

http://dx.doi.org/10.1016/j.biombioe.2014.10.019

Copyright: Elsevier

http://www.elsevier.com/

Postprint available at: Linköping University Electronic Press

http://urn.kb.se/resolve?urn=urn:nbn:se:liu:diva-113047 


\title{
Algae-based Biofuel Production as Part of an Industrial Cluster
}

Viktor Andersson $^{1 *}$, Sarah Broberg Viklund ${ }^{2}$, Roman Hackl ${ }^{1}$, Magnus Karlsson ${ }^{2}$, Thore Berntsson ${ }^{1}$

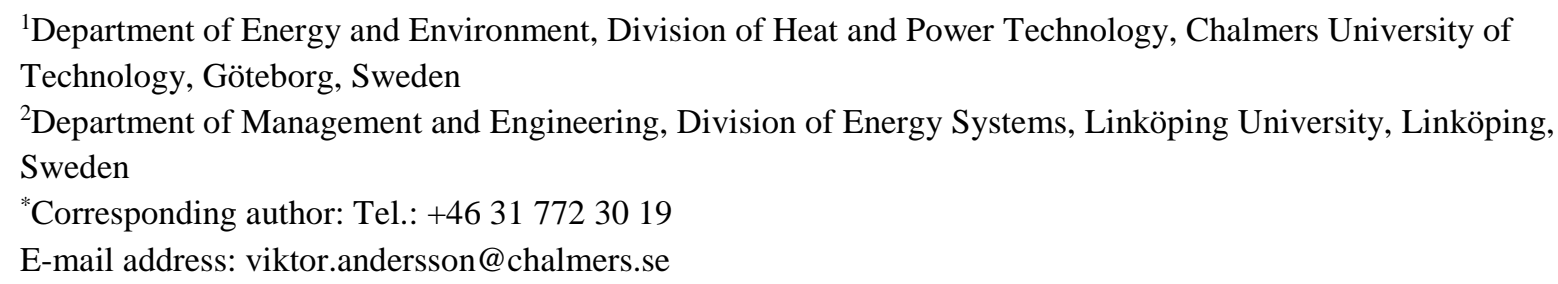

\begin{abstract}
This paper presents study on the production of biofuels from algae cultivated in municipal wastewater in Gothenburg, Sweden. A possible biorefinery concept is studied based on two cases; Case A) combined biodiesel and biogas production, and Case B) only biogas production. The cases are compared in terms of product outputs and impact on global $\mathrm{CO}_{2}$ emissions mitigation. The area efficiency of the algae-based biofuels is also compared with other biofuel production routes. The study investigates the collaboration between an algae cultivation, biofuel production processes, a wastewater treatment plant and an industrial cluster for the purpose of utilizing material flows and industrial excess heat between the actors. This collaboration provides the opportunity to reduce the $\mathrm{CO}_{2}$ emissions from the process compared to a stand-alone operation. The results show that Case A is advantageous to Case B with respect to all studied factors. It is found that the algae-based biofuel production routes investigated in this study has higher area efficiency than other biofuel production routes. The amount of algae-based biofuel possible to produce corresponds to $31 \mathrm{MW}_{\text {fuel }}$ for Case A and $26 \mathrm{MW}_{\text {fuel }}$ in Case B.
\end{abstract}

Key words: Algae, biofuel, biogas, biodiesel, biorefinery, wastewater treatment

\section{Nomenclature}

$\begin{array}{ll}\text { BOD } & \text { Biological Oxygen Demand } \\ \mathrm{CH}_{4} & \text { Methane } \\ \mathrm{CO}_{2} & \text { Carbon dioxide } \\ \mathrm{COD} & \text { Chemical Oxygen Demand } \\ \text { DME } & \text { Dimethylether } \\ \text { FAME } & \text { Fatty Acid Methyl Ester } \\ \text { FT-diesel } & \text { Fischer-Tropsch diesel } \\ \text { GHG } & \text { Green House Gas } \\ \text { LCA } & \text { Life Cycle Assessment } \\ \text { NGCC } & \text { Natural Gas Combined Cycle } \\ \text { SMHI } & \text { Swedish Meteorological and Hydrological Institute } \\ \text { TOC } & \text { Total Organic Carbon }\end{array}$


$\begin{array}{ll}\text { WW } & \text { Wastewater } \\ \text { WWT } & \text { Wastewater Treatment } \\ \text { WWTP } & \text { Wastewater Treatment Plant }\end{array}$

\section{Introduction}

The current use of fossil fuels is unsustainable due to its associated greenhouse gas (GHG) emissions and the depletion of fossil resources. To mitigate climate change, increase competitiveness and guarantee energy security for the region, the European Union (EU) has decided to transform into a highly efficient, low-carbon economy. The so-called "20-20-20" targets have been set and the key objectives are to reduce GHG emissions by $20 \%$ compared to the level of 1990 , to reduce the use of primary energy by $20 \%$ through energy efficiency measures, and to increase the share of renewable energy within the EU to 20\% [1]. Based on the directive for the promotion of the use of renewable resources, Sweden intends to increase the share of renewables in the transportation sector to at least $10 \%$ in 2020 [2].

First generation biofuels such as ethanol from wheat, biogas from corn and biodiesel from rapeseed oil have been criticized for their low land-use efficiency, increasing pressure on arable land, and poor carbon balance. The production of first generation biofuels has been linked to increasing emissions and rising food prices. Several studies bring forward the complexity and controversy of using food-biomass for biofuel, see e.g. Mitchell, Searchinger et al. and Timilsina et al.[3-5]. This has resulted in an effort to implement next-generation biofuels. These are mainly derived from lignocellulosic materials and algae and uses production routes such as gasification, transesterification, and liquefaction. Second generation biofuels are considered to have several advantages, e.g. a higher net energy output and biomass to biofuel efficiency, and higher area efficiency [6]. In this paper the term "biofuel" means biofuel for transportation and the term "algae" refers to microalgae.

The aim of this study is presented in Section 2. In order to give an overview of algae technology and algae-based biofuels a brief background to this area is given in Section 3. Looking at industrial processes as integrated systems may result in competitive advantages and Section 4 gives an introduction to the area of synergy effects and industrial symbiosis. Section 5 presents the cases studied and the methods used and assumptions made in the paper. Results from the study are given in Section 6 before the concluding discussion in Section 7.

\section{Aim}

The aim of this paper is to investigate the potential of a future possible biorefinery concept with respect to the amount of biofuels produced, $\mathrm{CO}_{2}$ emissions mitigation, area efficiency and heating requirements. The study investigates collaboration between several actors and the following aspects are included:

- A study investigating the replacement of a current wastewater treatment plant (WWTP) with a biorefinery concept consisting of a combined algae cultivation and WWTP (to utilize the nutrients available in the wastewater (WW) for algae cultivation), simultaneous wastewater treatment (WWT) and biofuel production. 
- A study investigating the collaboration between a WWTP and industrial plants for the purpose of utilizing nutrients and excess heat for algae cultivation. The study also includes calculations of the need for low grade heat for algae cultivation compared to the available excess heat in the region.

- An estimation of the potential for a reduction in $\mathrm{CO}_{2}$ emissions of an integrated algaebased WWT and biofuel production process.

- A comparison of the area efficiency of algae-based biofuels and other available biofuels.

\section{Algae technology}

Approximately $50 \mathrm{wt}-\%$ (dry) of algae biomass consists of carbon [7]. During cultivation an external carbon source, e.g. $\mathrm{CO}_{2}$ in flue gases from combustion, can be provided to increase the amount of carbon available which improves algal growth [8]. Additional nutrients, nitrogen and phosphorous, are needed and the minimal requirement of nutrients can be calculated by assuming the Redfield standard algae composition $\mathrm{C}_{106} \mathrm{H}_{181} \mathrm{O}_{45} \mathrm{~N}_{15} \mathrm{P}$ [9]. Either the nutrients needed can be added to the cultivation or the algae can be grown in a medium already containing the necessary nutrients [8]. In order to provide good growth conditions for algae a water temperature of $20-35^{\circ} \mathrm{C}$ is required for most species [10,11].

\subsection{Algae cultivation}

Algae are an interesting alternative for use as raw material for biofuel production because of their fast growth rate. Algae can be grown in open or closed systems, and open systems such as lakes or ponds can more easily be used for scaling up production since these are less technically complex than closed systems. The cultivation system should be designed so that solar radiation reaches all algal cells efficiently. Despite the large production capacity of open ponds, water temperature, vapour losses, $\mathrm{CO}_{2}$ diffusion to the atmosphere and the risk of contamination result in lower productivity than in closed systems. Closed systems, known as photobioreactors, offer a regulated and controlled cultivation environment and reduced risk of contamination. A large surface area also increases the amount of light that reaches the algae. In a photobioreactor the $\mathrm{CO}_{2}$ fixation efficiency increases compared to an open system due to good mixing possibilities [12]. In addition, thermal insulation is enhanced in closed systems compared to open systems but the scaling up of closed systems has other drawbacks, e.g. they are more expensive than open ponds and there are size limitations [7].

\subsection{Algae harvesting}

Following cultivation more than 99 wt- $\%$ of the algae/water mixture consists of water. No single technology has proven to efficiently increase the dry weight sufficiently, thus it is common to combine several harvesting technologies in a two-step process $[13,14]$. First, primary harvesting results in a solids content ranging from $0.5-6 \mathrm{wt}-\%$. Secondary harvesting is then used to further increase the solids content resulting in a solids content ranging from $10-20 \mathrm{wt}-\%$ [14]. Technologies used for harvesting and biomass concentration include centrifugation, flocculation, floatation, sedimentation and filtration $[7,12]$. 


\subsection{Algae-based biofuels}

Algae can be processed into a large variety of biofuels, such as hydrogen, bioethanol, biodiesel and biogas [8]. Before processing, the algae dry weight may need to be further increased. This is, however, not necessary if wet extraction of lipids is used for biodiesel production or in biogas production where the production processes accept a high moisture content [8]. Biodiesel is produced from algae lipids and approximately $20-50 \mathrm{wt}-\%$ of the algae (dry) consists of lipids, depending on algae species and growth conditions [15]. Biodiesel can be distributed through the existing infrastructure for petroleum diesel [16] and replace diesel in regular engines, despite a somewhat lower energy density [8]. Anaerobic digestion of biomass results in a biogas mixture of $55-70 \%$ methane $\left(\mathrm{CH}_{4}\right)$ and remaining part mostly $\mathrm{CO}_{2}[17,18]$. Biogas can be used for a range of applications such as on-site combustion for heat and electricity production, transportation fuel, or a substitute for natural gas. If used as transportation fuel the methane fraction must be higher than $95 \%$ and the gas must, therefore, be upgraded [19].

\section{Synergy effects}

The algae-based biofuel processes have advantages, but also drawbacks. Razon and Tan presented a study in which the process of algae-based biodiesel and biogas production has a negative energy balance [20]. The necessary nutrients in algae cultivation have, in several studies, been shown to have a large negative impact on the sustainability and economics of the process if artificial fertilizers are used [21-23]. Clarens et al. have analyzed several biomass based fuels (algae, corn, switch grass and canola) from a life cycle perspective in respect to land use, energy use, GHG emissions, water use and eutrophication, and came to the conclusion that land-based biomass had less environmental impact in most of the categories analyzed. In land use and eutrophication algae were, however, advantageous compared to the other raw materials. The large environmental impact from algae-based biofuels is mainly due to factors such as their demand for fertilizers and $\mathrm{CO}_{2}$, i.e. upstream impacts. Lardon et al. [24] performed an LCA on the production of biodiesel from microalgae. They concluded that the energetic balance is slightly positive or negative depending on assumptions, but did not include the possibility of using industrial excess heat. The by-product from biodiesel production, glycerol, has also been neglected although it can be used for e.g. anaerobic digestion. Razon and Tan [20] and Clarens et al. [21] came to the conclusions that it is essential to use $\mathrm{CO}_{2}$ and nutrients from alternative sources for algae cultivation, and that the overall freshwater and energy demand of the process need to be decreased. It has also been found that algae cultivation for biofuel production will not be economically feasible unless at least one other function, such as WWT or the production of valuable by-products, is fulfilled within the process [22,25]. A similar conclusion has been drawn by Olguín [26]. One limitation to algae cultivation in WW is the lack of carbon present in most domestic WWs [11,27]. Three ways to tackle these challenges are discussed in Razon and Tan [20] and Clarens et al. [21]. First, the way nutrients are delivered affects the environmental footprint of algae-based biofuels, and therefore offers a significant opportunity to reduce environmental impact. WW can provide both nutrients and water to the algae cultivation and thus reduce the need for fertilizers and fresh water. Also, $\mathrm{CO}_{2}$ can be recycled 
or obtained from flue gases from nearby power stations or other industrial sites. In addition, process integration for heat recovery within an algae biorefinery or heat integration with the surrounding infrastructure can be used to minimize the energy use in the process. Markou and Georgakakis [28] reviews the cultivation of algae in wastes and agro-industrial wastes. In line with previous research they conclude the benefits of using algae to reduce inorganic and organic pollutants. However, the authors bring forward drawbacks with using waste and WW as cultivation media for algae due to seasonal and composition variations [28]. This is likely not a problem in municipal WW since composition variations are small.

In recent years, the concept industrial symbiosis has gained interest in efforts towards sustainable consumption of world resources. It is argued that industrial processes should be looked upon as integrated systems, and industrial symbiosis should be seen as the exchange of resources, such as energy or by-products, between industries that can result in competitive advantages. These competitive advantages will affect the amount of resources used and the amount of waste and pollutants generated by the industries [29]. The impact of industrial collaborations has been studied in several studies, e.g. [23,30-32]. Martin and Eklund [32] have studied how excess heat from an ethanol plant can be used to improve the environmental performance of first generation biofuels. Wolf and Karlsson [30] have evaluated the environmental impact of possible industrial symbiosis in the forest industry compared to a stand-alone system, and found reduced $\mathrm{CO}_{2}$ emissions. Ellersdorfer and Weiss [31] have studied the effects of industrial cooperation where excess heat from a cement plant was used in a biogas production plant and where the biogas replaced fossil fuels in the cement plant, and found large $\mathrm{CO}_{2}$ emissions savings. Soratana and Landis [23] perform life cycle assessment (LCA) of the processes of strain selection and algae cultivation using an industrial symbiosis perspective. They came to the conclusion that an industrial symbiosis setup can result in environmental benefits for algae systems, showing that by using $\mathrm{CO}_{2}$ from flue gases the global warming potential can be reduced and by using WW as a cultivation medium eutrophication can be avoided. The possible benefits resulting from collaborations and industrial symbiosis may also be used in an extended algae system containing the production of algae-based biofuels.

\section{Methodology}

\subsection{Case study}

An industrial cluster on Hisingen, situated in Gothenburg on the Swedish west coast, is the object of study in this paper. Gothenburg is the second largest city in the country and its WWTP has a capacity of approximately 865000 person equivalent [33]. The WWTP is located on Hisingen along with several industrial sites, e.g. two oil refineries and a natural gas combined cycle (NGCC) power plant (i.e. there is an existing natural gas grid). The WWTP today produces approximately $8 \mathrm{MW}$ biogas through the co-digestion of sludge from the process and food waste collected from the region. The industrial plants produce large amounts of excess heat along with flue gases containing $\mathrm{CO}_{2}$. One of the two refineries has approximately $105 \mathrm{MW}$ of heat currently being cooled by utility below $90^{\circ} \mathrm{C}$ [34]. It was assumed that since the second refinery has $2 / 3$ of the crude oil capacity of the first refinery, 70 
MW is available at this facility which gives a total of $175 \mathrm{MW}$ heat. The case presented in this paper is based on a case study previously presented in Andersson et al. [35,36].

This study was conducted in order to investigate the potential of an algae-based biorefinery concept which may offer the advantageous synergy effects discussed in Section 4. The growth rate of the algae biomass was assumed to be within the span of $12-40 \mathrm{~g} \mathrm{~m}^{-2}$. day $^{-1}$ (see Section 5.4), because the growth rate strongly depends on algae species and cultivation conditions. Two cases, Case A and Case B, were compared with each other in respect to product output (biofuels), $\mathrm{CO}_{2}$ emissions consequences, and area efficiency. The results were then compared to the product output at today's WWT facility.

Case A - Algae cultivation for WWT and the production of both biogas and biodiesel.

Case B - Algae cultivation for WWT and the production of biogas.

In Case A, the cultivated algae biomass is transferred to a biodiesel production plant where algae lipids are extracted and used to produce biodiesel and the byproduct crude glycerol. The algae residues are further processed and upgraded into biogas. In Case B, the algae biomass is transferred directly to biogas production. Both cases assume integration with the industrial cluster on Hisingen and the system boundary is drawn so that the system includes the WWTP, the biofuel production unit, and the end-user of the biofuel. The $\mathrm{CO}_{2}$ produced and separated in the biogas upgrading step could in both cases be used in the algae cultivation. It was assumed that the same amount of algae is produced in both cases, which is the amount possible to cultivate with the nutrients available in the WWTP in Gothenburg for a period of 8000 hours per year. Figure 1 illustrates the two cases, the dashed line represents the system boundary. 


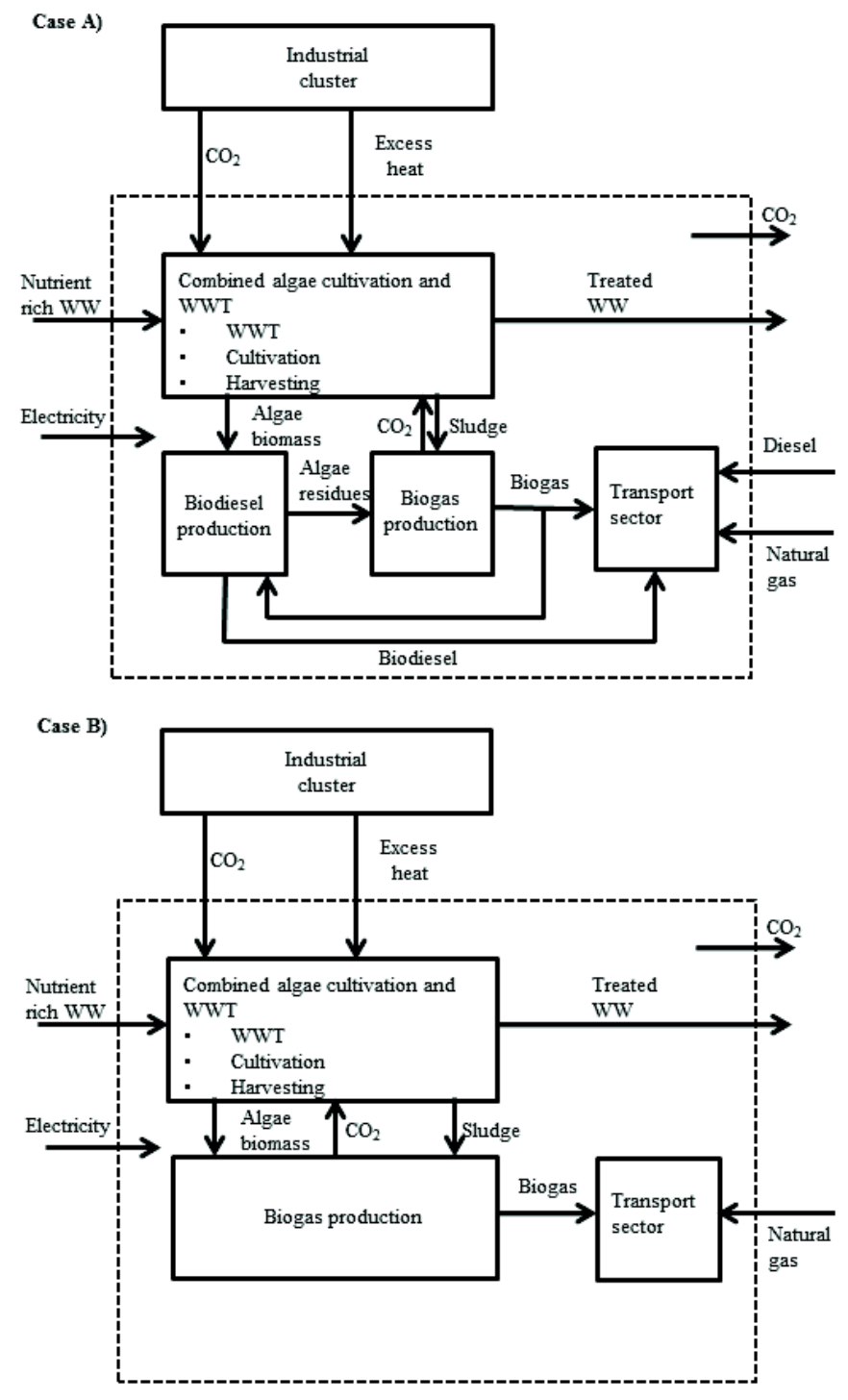

Figure 1. Material and energy flows for Case A) algae cultivation in conjunction with WWT and combined biodiesel and biogas production, and Case B) algae cultivation with WWT and biogas production. The system boundary is illustrated with the dashed line.

Some processes in the algae cultivation/biofuel production system need electricity and/or heat. Wherever this is the case, electricity is assumed to be produced in a coal power plant and heat is supplied either through excess heat from the industrial cluster (heating of the pond) or from combustion of biogas (heat to the production processes).

\subsection{Process selection and modeling}

A large variety of technologies can be used to cultivate and harvest algae in WW, and thereafter convert the biomass into fuels (see Section 3). This study investigates the treatment of the municipal WW of the city of Gothenburg. Data on incoming WW to the current WWTP in Gothenburg is shown in Table 1.

Table 1. Wastewater composition in Gothenburg's WWTP $[37,38]$.

\begin{tabular}{|l|l|l|}
\hline Parameter & Value $^{1}$ & Unit \\
\hline
\end{tabular}

\footnotetext{
${ }^{1}$ Average data for incoming sewage water is used.
} 


\begin{tabular}{|c|c|c|}
\hline $\mathrm{BOD}_{7}$ & 156 & $\mathrm{mg} \cdot \mathrm{lww}_{\mathrm{W}}{ }^{-1}$ \\
\hline TOC & 83 & $\mathrm{mg} \cdot \mathrm{l}_{\mathrm{WW}}{ }^{-1}$ \\
\hline COD & 360 & $\mathrm{mg} \cdot \mathrm{l}_{\mathrm{WW}}{ }^{-1}$ \\
\hline Total N & 30.8 & $\mathrm{mg} \cdot \mathrm{l}_{\mathrm{WW}}{ }^{-1}$ \\
\hline Free ammonia & 19.2 & $\mathrm{mg} \cdot \mathrm{l}_{\mathrm{WW}}{ }^{-1}$ \\
\hline Total P & 3.9 & $\mathrm{mg} \cdot \mathrm{l}_{\mathrm{WW}}{ }^{-1}$ \\
\hline Grease $^{2}$ & 100 & $\mathrm{mg} \cdot \mathrm{lww}_{\mathrm{W}}{ }^{-1}$ \\
\hline $\begin{array}{l}\text { Average flow } \\
\text { rate }^{3}\end{array}$ & 3833 & $l_{\mathrm{WW}} \cdot \mathrm{sec}^{-1}$ \\
\hline
\end{tabular}

Two models representing Case A and B were constructed. In the models, the primary sludge, oil and grease are separated from the WW, using sedimentation and floatation, and sent to anaerobic digestion. The WW is sent to open ponds where algae are cultivated and the WW is treated. The ponds are assumed to be $30 \mathrm{~cm}$ deep to ensure sufficient light throughout the whole cultivation and mixed by using a paddlewheel [40]. To calculate the amount of algae that can be cultivated using the available nutrients in the WW, the elemental formula $\mathrm{C}_{106} \mathrm{H}_{181} \mathrm{O}_{45} \mathrm{~N}_{15} \mathrm{P}$ [9] and the average annual WW flow was used. Based on these calculations it can be concluded that there is a carbon deficit. Therefore, additional carbon must be added from external sources. Necessary nutrients are present in the WW, while additional $\mathrm{CO}_{2}$ can be added from industrial sources and the biogas upgrading facility. The assumed energy requirements are $80 \mathrm{kWh} \cdot \mathrm{MlWw}^{-1}$ [27] for paddlewheel and $0.02 \mathrm{kWh}_{\mathrm{el}} \cdot \mathrm{kg}_{\mathrm{CO}_{2}}{ }^{-1}$ [9] for industrial $\mathrm{CO}_{2}$ injection.

A heat balance was made in order to estimate the heat demand of the algae cultivation pond. The pond was assumed to be well insulated against the ground and the heat balance is thus calculated according to Equation (1). The flow into the pond consists of water at $20{ }^{\circ} \mathrm{C}$.

Total heat flow from the pond $=$

+Solar radiation

- Convective heat transfer

-Water evaporation

The convective heat transfer was calculated using the Newton rate equation, Equation (2), where $\mathrm{q}$ is the heat transferred, $\mathrm{A}$ is the area of one pond, $\mathrm{h}$ is the convective heat transfer coefficient, and $\Delta \mathrm{T}$ is the temperature difference between the air and the pond. The algae cultivation will consist of several ponds, and one pond is assumed to be $6000 \mathrm{~m}^{2}$.

$$
q=A h \Delta T
$$

The convective heat transfer coefficient was calculated using Equation (3):

\footnotetext{
${ }^{2}$ Value for grease was not available for Gothenburg, therefore the medium value for WWs from [28] was used.

${ }^{3}$ Average flow rate is taken from June 2010 to May 2011 [27]
} 


$$
h=\frac{k N u}{L}
$$

where $\mathrm{k}$ is the conductive heat transfer capacity of air, $\mathrm{Nu}$ is the Nusselt number and $\mathrm{L}$ is the length in the flow direction. $\mathrm{L}$ was assumed to be $300 \mathrm{~m}$.

The Nusselt number was calculated via the Holman equation, Equation (4):

$$
\overline{N u_{x}}=\left(0.037 \operatorname{Re}_{x}^{\frac{4}{5}}-871\right) \operatorname{Pr}^{1 / 3}
$$

where Re is the Reynold's number and Pr is the Prandtl number, both of which were calculated using Equation (5) and Equation (6):

$$
\begin{gathered}
R e=\frac{\sigma_{\text {air }} V L}{\mu_{\text {air }}} \\
\operatorname{Pr}=\frac{v}{\alpha}
\end{gathered}
$$

where $\alpha$ is the thermal diffusivity of air, $\mu$ is the dynamic viscosity of air, $\sigma$ is the density of air, $v$ is the kinematic viscosity of air and $V$ is the wind speed.

Evaporation of water from the pool was calculated using the Ashrae model, Equation (7):

$$
W=\frac{(A+B v)\left(P_{w}-P_{a}\right)}{\Delta H_{v a p}}
$$

where $\mathrm{W}$ is the rate of water leaving the pond, $\mathrm{A}$ and $\mathrm{B}$ are constants, $\mathrm{v}$ is the air velocity, $\mathrm{P}_{\mathrm{w}}$ is the vapour pressure of water at pond temperature, $\mathrm{P}_{\mathrm{a}}$ is the vapour pressure at the air dewpoint temperature, and $\Delta \mathrm{H}_{\mathrm{vap}}$ is the heat of vapourization at pond temperature.

All weather data was taken from the Swedish Meteorological and Hydrological Institute (SMHI) [41]. The data contains the average values of Gothenburg during the years 20092011. All heat from the solar radiation that hits pond surface was assumed to be absorbed by the water.

Following cultivation, the algae-rich WW is sent to algae harvesting where the algae dry weight is increased in several steps (bio-flocculation, gravity thickening and centrifugation) to approximately $20 \mathrm{wt}-\%$. To prevent chemical flocculants from interfering in the biofuelproduction process, bio-flocculation was assumed [42]. Gravity thickening is a proven technology with low operating costs [40]. Centrifugation is used to further increase the dry weight prior the following biofuel production processes since it was assumed that solar drying is not applicable in Gothenburg due to the large area needed and local climate conditions. 
The algae biomass is then converted into biodiesel and/or biogas. In Case A, biodiesel is produced via transesterification of the lipids contained in the algae biomass. In a pretreatment step, the algae biomass is ground in a stirred ball mill [35], then lipids are extracted with solvent extraction using butanol. The extraction process is carried out at $90{ }^{\circ} \mathrm{C}$ [40]. The algae oil/butanol solution is sent to a stripper column for purification. In the transesterification step, $10 \mathrm{wt}-\%$ of the initial raw material ends up as the byproduct glycerol [16]. The residues from lipid extraction are sent to anaerobic digestion together with primary sludge from the WW treatment process and crude glycerol. The yield of lipids that can be extracted from algae biomass was assumed to be $90 \%$ [10]. In Case B, the algae biomass is sent directly to anaerobic digestion together with primary sludge from the WW treatment process [18]. Methanogenic bacteria convert the mixed substrate into raw biogas consisting of approximately 30 vol- $\% \mathrm{CO}_{2}$ and 70 vol- $\% \mathrm{CH}_{4}$ [18]. To increase the methane yield (33\% increase), the substrate is pretreated at $100{ }^{\circ} \mathrm{C}$ (in Case A this step was assumed to be replaced by the oil extraction step at $90{ }^{\circ} \mathrm{C}$ ) [43]. Water scrubbing [44] is used to increase the $\mathrm{CH}_{4}$ content to biogas quality (approximately 96 vol-\%). Industrial excess heat is considered as $\mathrm{CO}_{2}$ neutral in this paper. Detailed data on process parameters are given in supplementary data and in Andersson et al. [35].

\section{3 $\mathrm{CO}_{2}$ emissions reduction}

To evaluate the environmental consequences of the biorefinery concept, a $\mathrm{CO}_{2}$ emission evaluation was performed. Figure 2 illustrates the fuel and carbon flows with and without the combined algae WWT and biofuel production process.
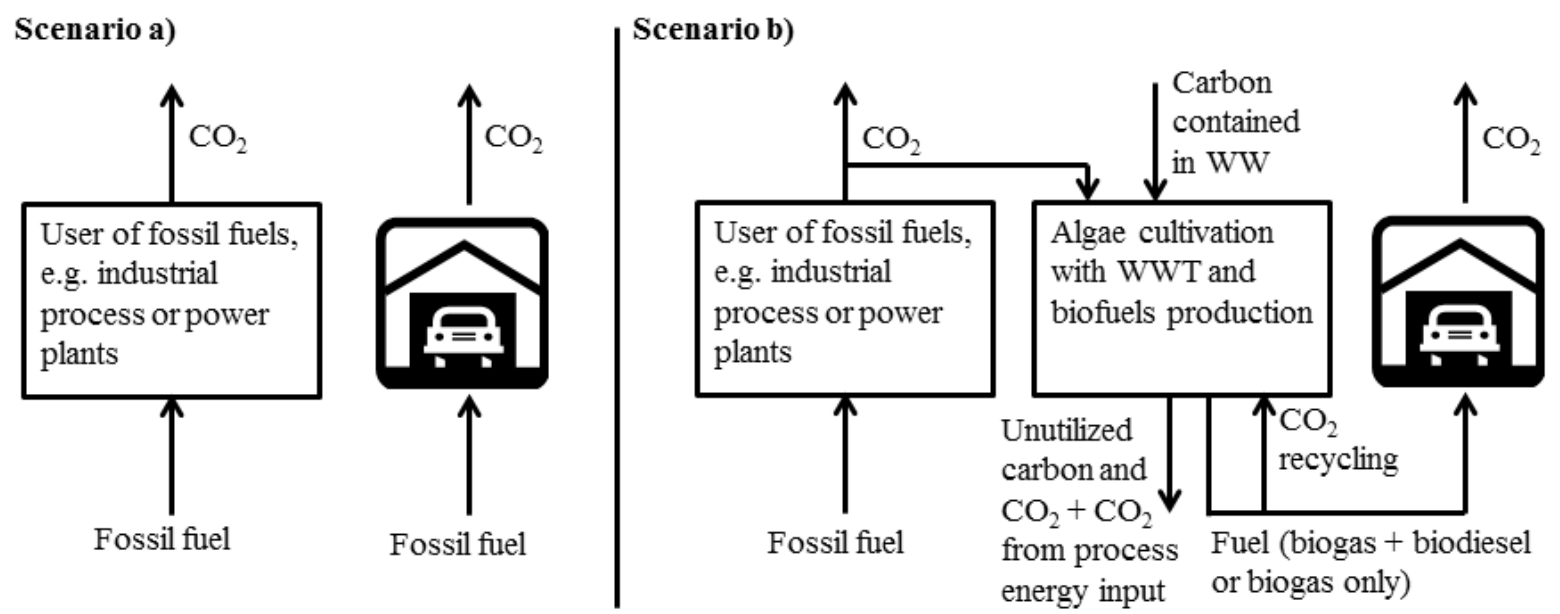

Figure 2. Fuel and carbon flows without (Scenario a) and with (Scenario b) the algae WWT and biofuel production process.

If no algae cultivation and biofuel production was assumed (Scenario a) both industrial processes and the transportation sector consume fossil fuels, which causes emissions of $\mathrm{CO}_{2}$. In the case in which biofuels are produced in the combined algae-WWT and algae-based biofuel production process (Scenario b), the biofuels are assumed to replace fossil fuels. This results in less consumption of fossil fuels, and can therefore be credited as a $\mathrm{CO}_{2}$ emissions saving. In addition, the conventional WWTP, a large consumer of electricity, was assumed to 
be replaced by the less energy demanding algae cultivation process. The amount of biogas currently produced at the WWTP has been subtracted from the $\mathrm{CO}_{2}$ savings.

Both processes (conventional WWT and combined algae-WWT and biofuel production) have a certain consumption of heat and electricity. Equation (8) summarizes the net $\mathrm{CO}_{2}$ emissions reduction when replacing fossil transportation fuels with biofuels from the algae-WWT and biofuel production process. That is, Equation (8) is used to calculate the change in $\mathrm{CO}_{2}$ emissions when implementing the biorefinery setup compared to the current situation, see Figure 2.

Total $\mathrm{CO}_{2}$ emissions reduction $=$

$+\mathrm{CO}_{2}$ emissions redustion from replacing fossil fuels

$-\mathrm{CO}_{2}$ emissions from energy inputs to the algae biofuels process

$+\mathrm{CO}_{2}$ emissions from energy inout to cinventional WWT

$-\mathrm{CO}_{2}$ emissions reduction from biofuels produced in conventional WWT (biogas)

The total amount of electricity used in the conventional WWTP today has been estimated to 4.5 MW, and the amount of biogas produced has been estimated to be approximately $8 \mathrm{MW}$ $[37,45] . \mathrm{CO}_{2}$ emission values for the different energy carriers are given in Table 2.

Table 2. $\mathrm{CO}_{2}$ emissions data for fuels and utilities.

\begin{tabular}{|l|l|l|l|}
\hline Energy carrier & Value & Unit & Comment \\
\hline Diesel & 258 & $\mathrm{~kg}_{\mathrm{CO} 2} \cdot \mathrm{MWh}^{-1}$ & $\begin{array}{l}\text { [46] corrected by difference in energy content of regular } \\
\text { diesel/biodiesel 35/32.6 } \mathrm{MJ} \cdot \mathrm{kg}^{-1}\end{array}$ \\
\hline Natural Gas & 230 & $\mathrm{~kg}_{\mathrm{CO} 2} \cdot \mathrm{MWh}^{-1}$ & Combustion of natural gas [46] \\
\hline Electricity & 722 & $\mathrm{~kg}_{\mathrm{CO} 2} \cdot \mathrm{MWh}^{-1}$ & Assuming marginal electricity from coal [47] \\
\hline Heat & 287.5 & $\mathrm{~kg}_{\mathrm{CO} 2} \cdot \mathrm{MWh}^{-1}$ & Assuming natural gas boiler with $\eta=0.8$ [47] \\
\hline
\end{tabular}

\subsection{Area efficiency}

When comparing area efficiency, Cases A and B have been compared to a number of other biofuel processes. Area efficiency is expressed in $\mathrm{MWh}_{\text {fuel }} \cdot \mathrm{ha}^{-1}$, and figures for non-algae based biofuels have been taken from Börjesson [48]. The biofuel routes were compared on a gross output basis which means that energy input to the process have not been taken into account. The biofuel production routes have been selected to give a diversified set of routes to compare to the algae-based biofuel process. The routes compared are shown in Figure 3.
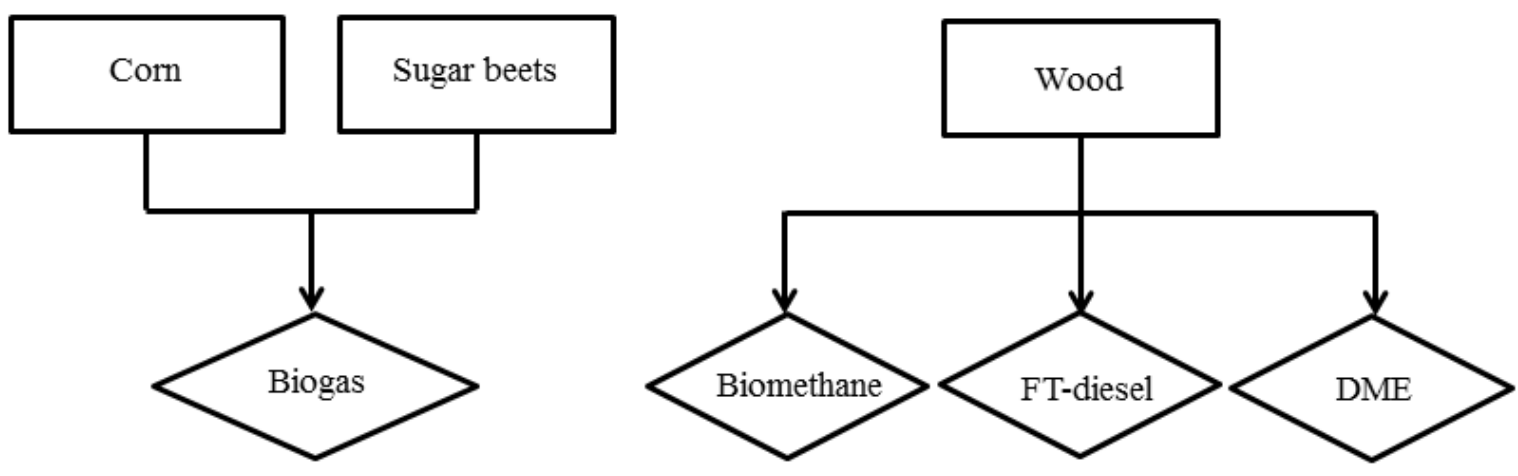
Figure 3. Process routes used for area efficiency comparison with the algae-based biofuel production routes. FT-diesel $=$ Fischer-Tropsch-diesel and DME $=$ dimethylether .

In Figure 3 all substrates based on waste products such as manure, sewage sludge and organic waste have been omitted. In Sweden the potential for biogas from waste products is estimated to $10-15 \mathrm{TWh} \cdot$ year $^{-1}$ [49]. Meanwhile, the need for transport fuel is around $120 \mathrm{TWh} \cdot \mathrm{year}^{-1}$ [50] which means that additional infusion of biofuels is needed in order to create a sustainable transport system. It is this additional part of the biofuel system that is considered here. The same trend is deemed to be valid also for the rest of Europe.

Since the growth rate for algae is highly dependent on solar radiation, two different growth rates have been used for calculations. The growth rates $12 \mathrm{~g} \cdot \mathrm{m}^{-2} \cdot \mathrm{day}^{-1}$ and $40 \mathrm{~g} \cdot \mathrm{m}^{-2} \cdot \mathrm{day}^{-1}$ are assumed constant throughout the year [11]. $40 \mathrm{~g} \cdot \mathrm{m}^{-2} \cdot$ day $^{-1}$ is a representative value for Swedish summer conditions, whereas $12 \mathrm{~g} \cdot \mathrm{m}^{-2} \cdot$ day $^{-1}$ is achievable during a 7-month period in Sweden (March - September) [35]. The growth rates are calculated using the conversion rate of $4.5 \%$ light utilization of algae [51] and a heating value of $21 \mathrm{~kJ} \cdot \mathrm{g}^{-1}$ [11]. The growth rate is then calculated through Equation (9) [11].

$$
\text { Growth rate }=\frac{I_{0} \eta}{\text { Algae heating value }}
$$

In Equation (9) $\mathrm{I}_{0}$ stands for average solar radiation and $\eta$ is the light utilization conversion rate. Averaged radiation values per month can be found in supplementary data.

\section{Results}

\subsection{Product output, heat and electricity consumption}

Based on the underlying assumptions presented in Section 5.2, the algae biomass that can be cultivated in the WW on Hisingen, and the amount of biofuels (biodiesel and/or biogas) that can be produced from this algae biomass was modeled. Table 3 shows the product output from each production stage of the combined algae-WWT and biofuel production process.

Table 3. Output from the different stages of the algae-WWT and biofuel production process (approximate numbers). FAME = Fatty Acid Methyle Ester.

\begin{tabular}{|l|l|l|l|}
\hline Stage & Output & Unit & Comment \\
\hline Algae WWT & $29^{4}$ & $\mathrm{kt}_{\text {algae }}$ year $^{-1}$ & \\
\hline $\begin{array}{l}\text { Biodiesel production } \\
\text { (Case A) }\end{array}$ & 8 & $\mathrm{MW}_{\text {biodiesel }}$ & $\begin{array}{l}\text { FAME } \\
\text { concentration } \\
96.5 \mathrm{wt}-\%\end{array}$ \\
\hline $\begin{array}{l}\text { Biogas production } \\
\text { (Case A) }\end{array}$ & 23 & $\mathrm{MW}_{\text {biogas }}$ & $\begin{array}{l}\mathrm{CH}_{4} \\
\text { concentration } 96 \\
\text { vol-\% }\end{array}$ \\
\hline $\begin{array}{l}\text { Biogas production } \\
\text { (Case B) }\end{array}$ & 26 & $\mathrm{MW}_{\text {biogas }}$ & $\begin{array}{l}\mathrm{CH}_{4} \\
\text { concentration } 96 \\
\text { vol-\% }\end{array}$ \\
\hline
\end{tabular}

${ }^{4}$ The annual amount of algae cultivated is based on 8000 production hours per year. 
As seen in Table 3, the amount of algae-based biofuel possible to produce in the Gothenburg WWTP corresponds to approximately $31 \mathrm{MW}_{\text {fuel }}$ for Case A and $26 \mathrm{MW}_{\text {fuel }}$ for Case $\mathrm{B}$, to be compared to the $8 \mathrm{MW}_{\text {fuel }}$ currently produced at Hisingen WWTP.

The lack of carbon in the WW leads to a need for additional $\mathrm{CO}_{2}$ of approximately $34 \mathrm{kt}_{\mathrm{CO} 2}$ per year. The $\mathrm{CO}_{2}$ is assumed to be supplied from industrial flue gases to decrease the environmental impact from the system, in accordance with the results presented in Razon and Tan [20] and Clarens et al. [21]. The consumption of heat and electricity for the different process steps and for the two cases is given in Table 4.

Table 4. Heat and electricity consumption for different stages of the algae-WWT and biofuel production process (approximate numbers).

\begin{tabular}{|c|c|c|c|}
\hline Stage & Input & Unit & Comment \\
\hline Algae-WWT (Case A) & 1.2 & $\mathrm{MW}_{\mathrm{el}}$ & \multirow{2}{*}{$\begin{array}{l}\mathrm{CO}_{2} \text { injection and paddlewheel; higher demand for } \\
\text { industrial } \mathrm{CO}_{2} \text { in Case A than in Case B since less biogas } \\
\text { is produced. }\end{array}$} \\
\hline Algae-WWT (Case B) & 1.1 & $\mathrm{MW}_{\mathrm{el}}$ & \\
\hline Algae harvesting & 1.7 & $\mathrm{MW}_{\mathrm{el}}$ & Bio-flocculation, gravity thickener and centrifugation \\
\hline \multirow{2}{*}{$\begin{array}{l}\text { Biodiesel production } \\
\text { (Case A) }\end{array}$} & 0.4 & $\mathrm{MW}_{\mathrm{el}}$ & Cell wall disruption with stirred ball mill \\
\hline & 1.7 & $\mathrm{MW}_{\text {heat }}$ & Butanol and methanol recovery, lipid extraction \\
\hline \multirow{3}{*}{$\begin{array}{l}\text { Biogas production } \\
\text { (Case A) }\end{array}$} & 0.5 & $\mathrm{MW}_{\mathrm{el}}$ & Anaerobic digester (mixing) \\
\hline & 0.6 & $\mathrm{MW}_{\text {heat }}$ & Anaerobic digester \\
\hline & 0.4 & $\mathrm{MW}_{\mathrm{el}}$ & Pressurized water scrubber \\
\hline \multirow{3}{*}{$\begin{array}{l}\text { Biogas production } \\
\text { (Case B) }\end{array}$} & 0.6 & $\mathrm{MW}_{\mathrm{el}}$ & Anaerobic digester (mixing) \\
\hline & 0.5 & $\mathrm{MW}_{\text {heat }}$ & Anaerobic digester \\
\hline & 0.4 & $\mathrm{MW}_{\mathrm{el}}$ & Pressurized water scrubber \\
\hline
\end{tabular}

The need for heating is largely dependent on season and several other factors, see Section 5.2. The pond temperature is set to be $20^{\circ} \mathrm{C}$, the lowest temperature required for good algae cultivation conditions. The amount of heating required for the cultivation pond in February was calculated to $112 \mathrm{MW}$, assuming a high growth rate, and to $372 \mathrm{MW}$, assuming a low growth rate. The heat demand for the lower growth rate exceeds the excess heat available from the refineries (175 MW), and calculations were, therefore, made to determine which months of the year that sufficient excess heat is available to maintain the pond at $20^{\circ} \mathrm{C}$. The need for heating exceeds the heat available at the refineries during four months of the year (November-February), assuming the lower growth rate. If the higher growth rate is assumed, then, the available excess heat is sufficient to maintain the pond at $20^{\circ} \mathrm{C}$ during all months except December. The excess heat from the refinery is not needed at all seven months of the year (March-September) in any of the cases. This means that the months during which the low growth rate cannot be achieved, see Section 5.4, overlap the months during which industrial excess heat is not sufficient to heat the pond.

\section{2 $\mathrm{CO}_{2}$ emissions reduction}

The consequences of $\mathrm{CO}_{2}$ emissions from the production of algae-based biofuel in combination with algae cultivation in municipal WW and the replacement of fossil fuels with 
these biofuels have been estimated. Reductions in $\mathrm{CO}_{2}$ emissions for Case A and Case $\mathrm{B}$ compared to the current situation are shown in Figure 4.

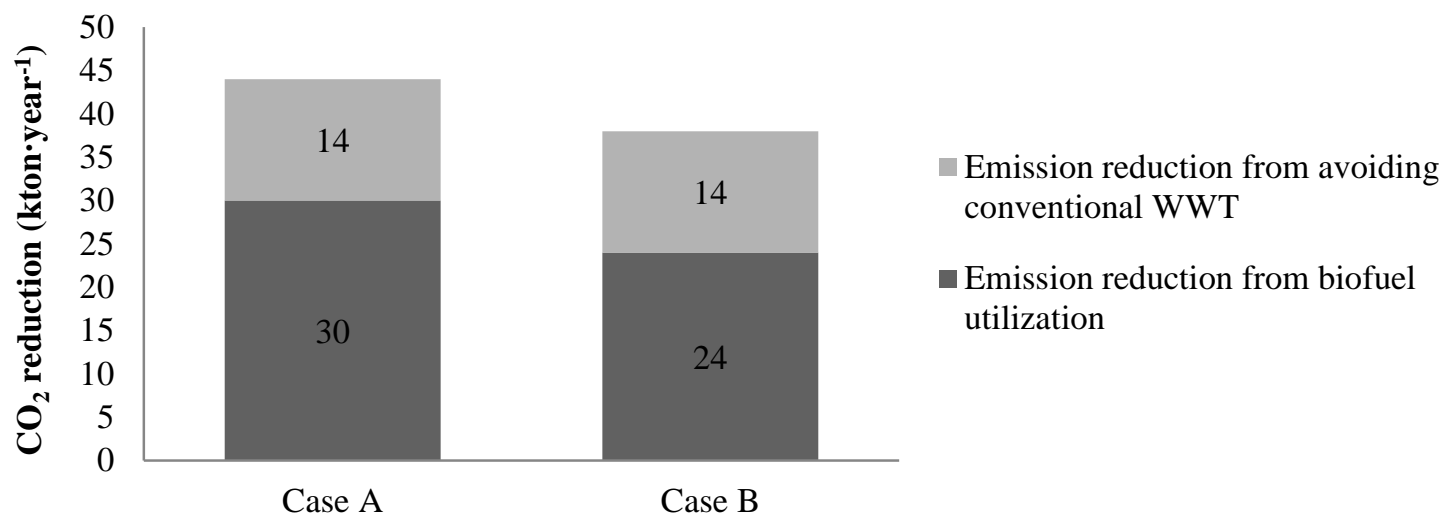

Figure 4. Total reduction in $\mathrm{CO}_{2}$ emissions by replacing fossil fuels with biofuels from algal biomass cultivated in municipal WW compared to the current situation.

It can be seen that in Case $\mathrm{A}$, a higher total savings in $\mathrm{CO}_{2}$ emissions can be achieved than in Case B. This is mainly due to the high material efficiency of the biodiesel process. Figure 4 also indicates the reduction in $\mathrm{CO}_{2}$ emissions obtained by cultivating algae in conjunction with municipal WWT. WWT stands for approximately $14 \mathrm{kt}$ of the net ${ }^{5}$ savings in $\mathrm{CO}_{2}$ emissions per year, corresponding to $24 \%$ of the savings in Case A and $34 \%$ of the savings in Case B. This shows the synergy advantages of combining the production of algae-based biofuels with another function, in this case WWT. In order to cover the lack of carbon in the $\mathrm{WW}, 24 \mathrm{kt}_{\mathrm{CO} 2}$ per year in Case $\mathrm{A}$ and $23 \mathrm{kt}_{\mathrm{CO} 2}$ per year in Case $\mathrm{B}$ must be added during the cultivation stage in addition to the $\mathrm{CO}_{2}$ recirculated from the biogas production.

\subsection{Area efficiency}

The required area for algae cultivation in these case studies varies with the assumed growth rates. The resulting pond sizes and the specific area can be seen in Table 5.

Table 5. Pond size and specific area for the two studied growth rates in each of the two cases.

\begin{tabular}{|l|l|l|l|}
\hline Case & $\begin{array}{l}\text { Growth rate } \\
{\left[\mathbf{g} \cdot \mathbf{m}^{-\mathbf{2}} \cdot \mathbf{d a y}^{-1}\right]}\end{array}$ & Pond size [ha] & $\begin{array}{l}\text { Specific Area } \\
{\left[\mathbf{M W h} \cdot \mathbf{h a}^{-\mathbf{1}} \mathbf{y e a r}^{-\mathbf{1}} \mathbf{]}\right.}\end{array}$ \\
\hline $\mathrm{A}$ & 12 & 720 & 340 \\
\hline $\mathrm{A}$ & 40 & 220 & 1130 \\
\hline $\mathrm{B}$ & 12 & 720 & 290 \\
\hline $\mathrm{B}$ & 40 & 220 & 950 \\
\hline
\end{tabular}

\footnotetext{
${ }^{5}$ Net emissions $=\mathrm{CO}_{2}$ emissions from energy inputs $\left(\mathrm{ca} 27 \mathrm{kt} \cdot\right.$ year $\left.{ }^{-1}\right)-\mathrm{CO}_{2}$ reduction from today's biogas production at the WWTP $(\mathrm{ca}$ $13.4 \mathrm{kt} \cdot$ year $\left.^{-1}\right)$.
} 
It should be noted that the lower growth rate is achievable seven months of the year with the solar radiation that reaches Gothenburg. This means that the amount of algae-based biofuel that is possible to produce, in reality, is complicated to calculate. In order to produce the amount of biofuel presented in Table 3, which assumes an even production rate throughout the year, the production must be larger during the summer than the winter. This will be discussed in Section 7.

A comparison with other biofuels is illustrated in Figure 5. It should be noted that the values given are gross output and not the net yield. It can be seen that algae-based biofuels yield between 7 - 31 times more biofuel per hectare than the closest competitor, biogas from sugar beets. This assumes operation of the algae pond throughout the year. The results show that algae have a large benefit in terms of area efficiency.

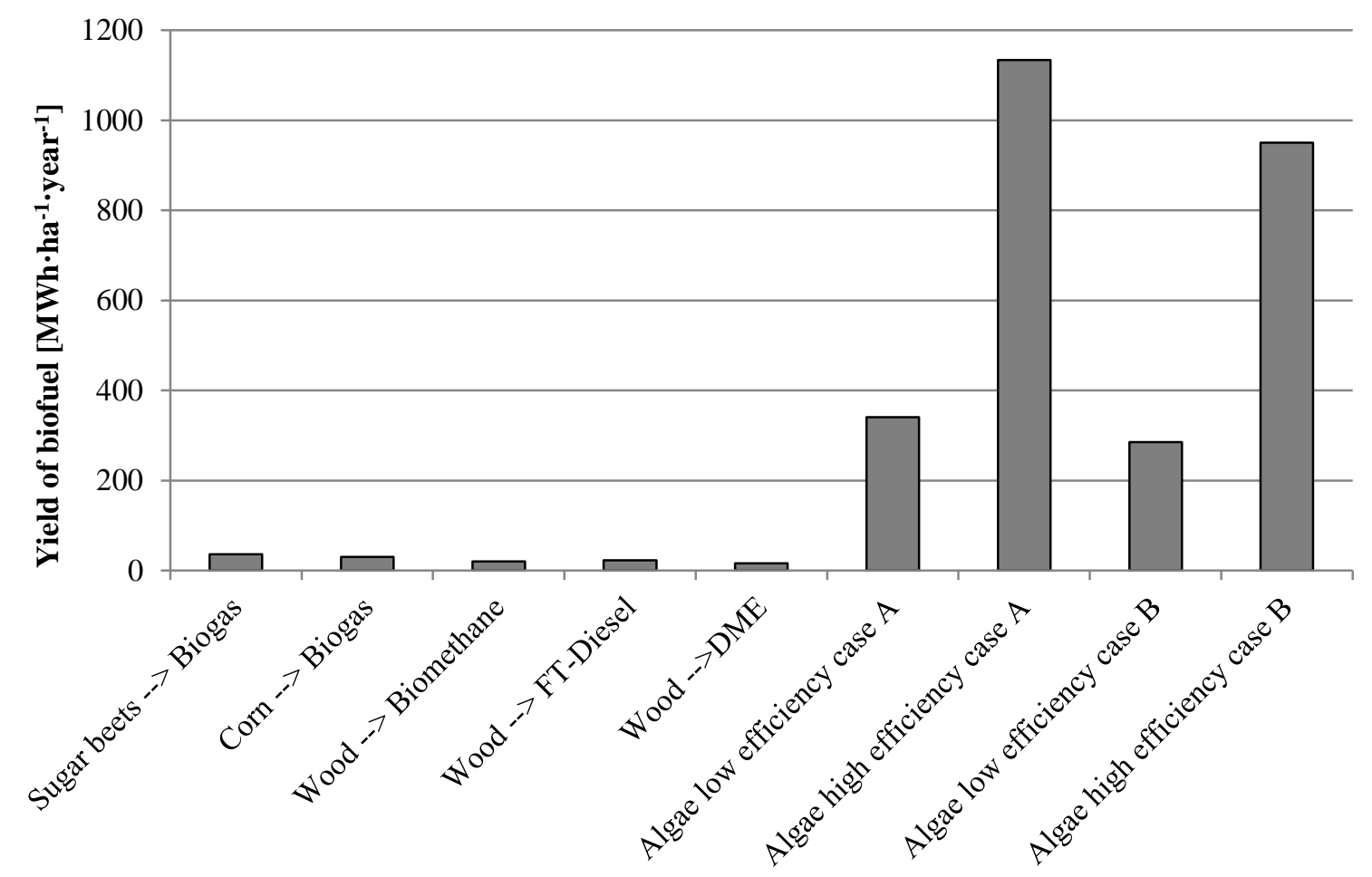

Figure 5. Area efficiency of different biofuel routes [48].

\section{Concluding discussion}

The assumed technologies in this study, especially for cultivation and harvesting, are not yet fully developed. The lack of large-scale facilities means a lack of reliable data, a problem that has also been discussed in Olguín [26]. Future research on algae-based energy is, thus, dependent on demonstration plants. As these plants are built and knowledge increases, the efficiency of the technology may increase and production costs decrease.

There are major uncertainties about how the growth rate of algae is affected by the climate conditions in Gothenburg. The assumed broad span of $12-40 \mathrm{~g} \cdot \mathrm{m}^{-2} \cdot \mathrm{day}^{-1}$ leads to uncertain conclusions regarding area efficiency and the heating requirements for the pond. The climate 
conditions also raise questions about which seasons of the year the process is available. Severe problems with heat losses occur during winter, and supplementary light and heat would probably have to be supplied in order to maintain full operation. It could therefore be argued that a seasonal production would be more suitable for Gothenburg, but this would have implications on the amount of biofuels produced and the economy of the investment. Another option would be to use a closed cultivation system, which offers a cultivation environment that is easier to control. However, closed systems are currently more expensive than open ponds.

It is difficult to dimension the system since algae growth rates differ during different months of the year. If the system is dimensioned for summer conditions with a high growth rate, the pond area will be too small to handle the wastewater during winter when the growth rate is lower. If the system is dimensioned for winter conditions, large parts of the system will be unutilized during summer. This factor, in combination with the fact that a sufficient amount of heat is not available to offer good growth conditions during the winter, makes seasonal production more suitable for Gothenburg. If heat is to be supplied using designated boilers, the carbon balance would change. Lardon et al. [24] showed uncertain energy balance for biodiesel production from microalgae, whereas Martin and Eklund [32] showed that the use of excess heat in first generation biofuel processes is beneficial and this study shows that excess heat utilization can be beneficial also in second generation biofuel systems. The solar radiation during some seasons of the year is not sufficient for achieving even the lower growth rate. Extra lighting could be provided, but it would also shift the carbon balance in an unfavorable direction. A possible solution to the discrepancy in cultivation conditions could be to install an accumulation tank to store wastewater during winter, but the amount of wastewater treated would, then, have to increase during the summer months (the pond would be designed for summer conditions). Another solution would be to recirculate nutrients from the biogas plant in the summer to better use the full area of the pond (the pond would be designed for winter conditions).

The area efficiency of algae-based biofuels is with the assumptions made in this paper superior to other second generation biofuel routes such as gasification. The difference in area efficiency is larger than what was reported in Clarens et al. [21], who performed an LCA on biomass growth but did not include the biofuel production step. However, it is significantly smaller than the area efficiency estimates given by Williams et al. [52]. Since the nutrient supply via WW is important in order to gain sustainable algae cultivation, the maximum amount of biomass is not (in this study) dependent on area, but rather on the availability of WW. If algae are cultivated without WWT, then the nutrients contained in the WW will have to be replaced with artificial fertilizers, which results in additional $\mathrm{CO}_{2}$ emissions. The amount of algae-based biofuel possible to produce in Gothenburg is far from enough to make algae-based biofuel the dominant fuel for the regional transport energy system. It can, however, be a significant part of a diversified energy system in which different fuel routes are used. It must also be noted that the area efficiency calculations only take the amount of fuel produced into account, and not the energy input in the processes. As this study shows, large amounts of heat and electricity are required for cultivation before the algae reaches the biofuel 
process. In traditional biofuel process routes, that energy is not needed during the cultivation phase. The findings indicate that it would be interesting to perform a full LCA of the algalbased biofuel process including the utilization of industrial excess heat, as well as an economic analysis of the biorefinery concept.

The lower growth rate used in this study requires a 720 hectare pond, while the higher growth rate requires a 220 hectare pond. These areas are substantially smaller than the area required to produce the same amount of biofuels with the other biofuel routes discussed in this article. However, the area is nevertheless large. Since municipal WWT takes place in populated areas this could make capital costs for ponds unfeasibly large. The geographical location may also make the supply of heat to the pond difficult. The two refineries available on Hisingen in Gothenburg are not sufficient for heating the pond with a constant temperature of $20^{\circ} \mathrm{C}$ all year round. Without excess heat the entire amount of heat required for cultivation would have to be supplied by another source. This would increase the use of primary energy in the process to a large extent and would therefore change the carbon balance. Algae cultivation without the use of industrial excess heat can for this reason be ruled out.

Previous studies discuss the importance of combining several functions to reduce the environmental impact associated with algae cultivation and algae-based systems, see Section 4. The importance of e.g. using $\mathrm{CO}_{2}$ from flue gases and $\mathrm{WW}$ as nutrient sources in algae cultivation is discussed and quantified and the positive effects on $\mathrm{CO}_{2}$ emission mitigation through a collaborative biorefinery concept are shown in this paper. Numerous papers have discussed the positive effects of adding several functions when producing algae-based biofuel and how artificial nutrients can shift the energy balance from positive to negative. In this paper this advantage is also quantified from another point of view; not only does the algae cultivation receive "free" nutrients, but energy is also saved by avoiding the need for conventional WW treatment. Introducing algae-based WWT in the system stands for a large share of the emission reduction associated with the studied system. Also, the importance of using available excess heat to heat the cultivation pond is discussed in the paper.

\section{Acknowledgements}

This work was carried out under the auspices on the Energy Systems Programme, which is funded primarily by the Swedish Energy Agency. The authors would like to thank Simon Harvey and Eva Albers at Chalmers University of Technology for valuable comments and input.

\section{References}

[1] European Comission. The EU climate and energy package - Policies - Climate Action European Commission 2010.

[2] Näringingsdepartementet. Swedens national agenda for supporting renewable energy Sveriges nationella Handlingsplan för främjandet av förnybar energi enligt Direktiv 2009/28/EG och Kommissionens beslut av den 30.6.2009. Regeringskansliet; 2010.

[3] Mitchell D. A Note on Rising Food Prices 2008. 
[4] Searchinger T, Heimlich R, Houghton RA, Dong F, Elobeid A, Fabiosa J, et al. Use of U.S. croplands for biofuels increases greenhouse gases through emissions from land-use change. Science 2008;319:1238-40.

[5] Timilsina GR, Beghin JC, van der Mensbrugghe D, Mevel S. The impacts of biofuels targets on land-use change and food supply: A global CGE assessment. Agricultural Economics 2012;43:315-32.

[6] Schenk PM, Thomas-Hall SR, Stephens E, Marx UC, Mussgnug JH, Posten C, et al. Second Generation Biofuels: High-Efficiency Microalgae for Biodiesel Production. Bioenergy Research 2008;1:20-43.

[7] Demirbas A. Use of algae as biofuel sources. Energy Conversion and Management 2010;51:2738-49.

[8] Posten C, Schaub G. Microalgae and terrestrial biomass as source for fuels--a process view. Journal of Biotechnology 2009;142:64-9.

[9] Davis R, Aden A, Pienkos PT. Techno-economic analysis of autotrophic microalgae for fuel production. Applied Energy 2011;88:3524-31.

[10] Pokoo-Aikins G, Nadim A, El-Halwagi MM, Mahalec V. Design and analysis of biodiesel production from algae grown through carbon sequestration. Clean Technologies and Environmental Policy 2009;12:239-54.

[11] Park JBK, Craggs RJ, Shilton AN. Wastewater treatment high rate algal ponds for biofuel production. Bioresource Technology 2011;102:35-42.

[12] Ho S-H, Chen C-Y, Lee D-J, Chang J-S. Perspectives on microalgal CO2-emission mitigation systems - A review. Biotechnology Advances 2011;29:189-98.

[13] Mata TM, Martins AA, Caetano NS. Microalgae for biodiesel production and other applications: A review. Renewable and Sustainable Energy Reviews 2010;14:217-32.

[14] Wiley PE, Campbell JE, McKuin B. Production of Biodiesel and Biogas from Algae: A Review of Process Train Options. Water Environmental Research 2011;83:326-38.

[15] Chisti Y. Biodiesel from microalgae. Biotechnology Advances 2007;25:294-306.

[16] Astals S, Ariso M, Galí A, Mata-Alvarez J. Co-digestion of pig manure and glycerine: Experimental and modelling study. Journal of Environmental Management 2011;92:1091-6.

[17] Jørgensen PJ. Biogas - Green Energy: Process, Design, Energy Supply, Environment. Researcher for a Day; 2009.

[18] Collet P, Hélias A, Lardon L, Ras M, Goy R-A, Steyer J-P. Life-cycle assessment of microalgae culture coupled to biogas production. Bioresource Technology 2011;102:207-14.

[19] Energigas Sverige. Upgrading - Uppgradering. Biogasportalen 2011.

[20] Razon LF, Tan RR. Net energy analysis of the production of biodiesel and biogas from the microalgae: Haematococcus pluvialis and Nannochloropsis. Applied Energy 2011;88:3507-14.

[21] Clarens AF, Resurreccion EP, White MA, Colosi LM. Environmental Life Cycle Comparison of Algae to Other Bioenergy Feedstocks. Environmental Science \& Technology 2010;44:1813-9.

[22] Savage N. Algae: The scum solution. Nature 2011;474:S15-S16.

[23] Soratana K, Landis AE. Evaluating industrial symbiosis and algae cultivation from a life cycle perspective. Bioresource Technology 2011;102:6892-901.

[24] Lardon L, Hélias A, Sialve B, Steyer J-P, Bernard O. Life-Cycle Assessment of Biodiesel Production from Microalgae. Environmental Science \& Technology 2009;43:6475-81.

[25] Pittman JK, Dean AP, Osundeko O. The potential of sustainable algal biofuel production using wastewater resources. Bioresource Technology 2011;102:17-25. 
[26] Olguín EJ. Dual purpose microalgae-bacteria-based systems that treat wastewater and produce biodiesel and chemical products within a Biorefinery. Biotechnology Advances 2012;30:1031-46.

[27] Craggs RJ, Heubeck S, Lundquist TJ, Benemann JR. Algal biofuels from wastewater treatment high rate algal ponds. Water Science \& Technology 2011;63:660.

[28] Markou G, Georgakakis D. Cultivation of filamentous cyanobacteria (blue-green algae) in agro-industrial wastes and wastewaters: A review. Applied Energy 2011;88:3389401.

[29] Chertow MR. "Uncovering” industrial symbiosis. Journal of Industrial Ecology 2007;11:11-30.

[30] Wolf A, Karlsson M. Evaluating the environmental benefits of industrial symbiosis: discussion and demonstration of a new approach. Progress in Industrial Ecology, an International Journal 2008;5:502-17.

[31] Ellersdorfer M, Weiss C. Integration of biogas plants in the building materials industry. Proceeding of WREC, Linköping, Sweden: 2011.

[32] Martin M, Eklund M. Improving the environmental performance of biofuels with industrial symbiosis. Biomass and Bioenergy 2011;35:1747-55.

[33] Demirbas A, Fatih Demirbas M. Importance of algae oil as a source of biodiesel. Energy Conversion and Management 2011;52:163-70.

[34] Gottfridsson R, Johansson I. Investigation of the opportunity for heat integration at Preemraff Göteborg. Master's Thesis. Chalmers University of Technology, 2011.

[35] Andersson V, Broberg S, Hackl R. Integrated Algae Cultivation for Biofuels Production in Industrial Clusters. Linköping, Sweden: Program Energisystem; 2011.

[36] Andersson V, Broberg S, Hackl R. Integrated algae cultivation for municipal wastewater treatment and biofuels production in industrial clusters. vol. 1, 2012, p. 684 91.

[37] Davidsson F. Annual environmental report 2010 - Miljörapport enligt miljöbalken 2010. Göteborg, Sweden: Gryaab; 2011.

[38] Gryaab AB. Current treatment results - Aktuella reningsresultat 2011.

[39] Tchobanoglous G, Burton FL, Stensel HD. Wastewater Engineering: Treatment and Reuse. 4th ed. McGraw-Hill Science/Engineering/Math; 2002.

[40] Lundquist TJ, Woertz IC, Quinn NWT, Benemann JR. A Realistic Technology and Engineering Assessment of Algae Biofuel Production. University of California, Berkley: Energy Bioscience Institute; 2010.

[41] SMHI. SMHI Strålning 2011.

[42] Rawat I, Ranjith Kumar R, Mutanda T, Bux F. Dual role of microalgae: Phycoremediation of domestic wastewater and biomass production for sustainable biofuels production. Applied Energy 2011;88:3411-24.

[43] Sialve B, Bernet N, Bernard O. Anaerobic digestion of microalgae as a necessary step to make microalgal biodiesel sustainable. Biotechnology Advances 2009;27:409-16.

[44] Götz M, Köppel W, Reimert R, Graf F. Optimisation potential of washing processes for biogas upgrading - Optimierungspotenzial vom Wäschen zur Biogas-aufbereitung 2011.

[45] Khoo HH, Sharratt PN, Das P, Balasubramanian RK, Naraharisetti PK, Shaik S. Life cycle energy and $\mathrm{CO} 2$ analysis of microalgae-to-biodiesel: preliminary results and comparisons. Bioresource Technology 2011;102:5800-7.

[46] Engineering ToolBox. Combustion Fuels - Carbon Dioxide Emission 2011.

[47] Harvey S, Axelsson E. Scenarios for assessing profitability and carbon balances of energy investments in industry. Chalmers University of Technology; 2010. 
[48] Börjesson P. Upgrading and consumption of agricultural based biofuels - Förädling och avsättning av jordbruksbaserade biobränslen. Lund: Avdelning Miljö- och energisystem; 2007.

[49] Swedish Gas Association. Biogas in Sweden 2011.

[50] Swedish Energy Agency. Energy in Sweden 20132013.

[51] Walker DA. Biofuels, facts, fantasy, and feasibility. Journal of Applied Phycology 2009;21:509-17.

[52] Williams PRD, Inman D, Aden A, Heath GA. Environmental and sustainability factors associated with next-generation biofuels in the U.S.: What do we really know? Environmental Science and Technology 2009;43:4763-75. 